\title{
Cause and Impact of Dispute and Delay the Closing of Final Account in Malaysia Construction Industry
}

\author{
Zarabizan Zakaria $^{1}$, Syuhaida Ismail ${ }^{1}$ and Aminah Md. Yusof ${ }^{2}$ \\ ${ }^{1}$ RAZAK School of Engineering and Advanced Technology, University of Technology Malaysia, \\ Kuala Lumpur, Malaysia \\ ${ }^{2}$ Faculty of Civil Engineering, University of Technology Malaysia, Malaysia
}

\begin{abstract}
Construction industry is realizing the plans and specifications for the physical structure. The project is success when it is completed to meet customer needs without any issues and problems in terms of time, quality and budget allocation. The budget allocation is important especially to get the total final cost of the project that will be added in the final accounts. Final account is the fact that the sum agreed to be paid at the end of the contract by the owner to the contractor. Moreover, the final account issue has existed in Malaysia construction industry for several decades in which the important factors significantly affect the closing of final account that related with contractor, management and the contract as well. Successful closing is categorized as resolved at the stipulated time without any problems in the dispute and delay. Therefore, the purpose of this paper is to investigate the important factors that contribute to the closing of final account in construction projects in Malaysia. This aim can be achieved through the objectives of evaluating the contract in Malaysia to compare the final closure of various forms of contract and finally identify the causes and effects of the dispute and delays in the final account closing. As a result, this paper can assist construction industry players to create more effective planning and be used as guidelines in ensuring the on-time closing of final account in constructions projects in Malaysia.
\end{abstract}

Keywords: Dispute, delay, closing of final account, Malaysia construction industry.

\section{Introduction}

The building and construction industry encompasses housing, commercial, and infrastructure development. Low (1994) argues that the construction industry has a direct bearing on the national economy and consequently, can be used as an indicator of economic well-being for a country. Thus, the effect of construction on the economy through the production process and through the effects of credit constraint can be as important as the effect of the economy on the construction sector (Tse, 1997). This is because the construction sector comprises various fields including architecture, civil engineering, mechanical engineering, electrical engineering, quantity surveying, land surveying, building contracting, and landscaping, among others (Chow, 1993). The consultant and contractor are drawn together by a common purpose to build a building project for a person or an organization called the client (Rosli, 1988). Once a project is completed and handed over to the client, their work ends there.

Copyright (C) 2012 Zarabizan Zakaria, Syuhaida Ismail and Aminah Md. Yusof. This is an open access article distributed under the Creative Commons Attribution License unported 3.0, which permits unrestricted use, distribution, and reproduction in any medium, provided that original work is properly cited. Contact author: Zarabizan Zakaria E-mail: zarabizan2@live.utm.my 
Therefore, it is undoubted that construction industry plays an important role in generating wealth and improving the quality of life through the translation of government's social-economic policies into social and economic infrastructures and buildings. For this reason, a sum of RM230 billion has been allocated for development under the $10^{\text {th }}$ Plan from Malaysia governments (EPU, 2010). Furthermore, the construction industry creates a multiplier effect to other industries, including manufacturing, financial services and professional services. However at the same time, there is a lot of problems faced by Malaysia construction industry, which will effect to the productivity of construction industry in terms of manpower, quality of productivity, time and payment issue especially during the closing of final accounts in construction projects. Nevertheless, as various efforts have been taken by the Government in sustaining Malaysia construction industry to ensure its supports to other industries, the Malaysian economy grew by $4.7 \%$ (FY2010: 5.4\%) on growth in private consumption and sustained robust expansion in gross fixed capital formation amid the consolidation in Government outlays and moderate external trade growth (Maybank, 2011).

According to the records provided by Construction Industry Development Board Malaysia (CIDB) (2012), the total number of projects until March 2012 is 655 with value of RM 9,399.09 million. Theproject wasawarded to local contractors is 652 with a total value RM $9,109.53$ million and foreign contractors is 3 with a total value is RM 289.56 million. The number of private projects generally exceeds the number of government projects, regardless the status of contractor.

Having conferred the construction industry in general, construction projects consist of four stages, namely design/planning stage, tender stage, construction stage and final account/defect liability stage or being referred to as post-contract. The role and performance of various project participants and contracting parties in a construction project in each stage can influence the project success. Post contract is the process to summarise all progress of works and evaluate all variations and prepare the final account. In practice, the closing final account should be completed after the expiry of defect liability period. In basic terms, final account in construction contracts is defined as the agreed statement of the amount of money to be paid at the end of a project contract by the owner to the contractor.

When unforeseen situations occur on site, it is important to first understand the situation and come up with suitable solutions and forecast the problematic consequences. The timing of payments is said to be a key element of a contractor's profitability performance (Strischek, 1995).It will bring inconveniences to all the parties involved in the construction industry, mainly the client, consultants and the most important, the contractors. On the other hand, it also brings inconvenience to the end user because the final accounts remained unresolved after the building is occupied. This is supported by Odeyinka and Kaka (2005) through their surveys on the impact of the payment terms of cash flow which found that contractors were dissatisfied with the time lag to receiving payment.

However, effective management can assist in ensuring that payments are made to the related parties in accordance with the proper amount within the specified time and also settled without any issues and problems. According to Chen and Chen (2005) who report a survey of contractors on time lags, and components and frequency of payments, payment condition patterns are seen to differ between the public sector and the private sector. Adams (2008), based on surveys, establishes subjective probabilities on payment delays. Uher (1991), Hinze and Tracey (1994), Bennett and Ferry (1990) and Arditi and Chotibhongs (2005) note the impact on specialist contractors of payment time lags and late payments. Navon (1995) on the other hand highlights the connection 
between work performance and payment. The dispute and delays in construction project are therefore observed by this paper as among the factors affecting the closing of final accounts in construction project.

Based on this, some strategies are needed to anticipate any problems that may occur from the planning stage, so that the on-site issue can be determined and minimized during the closing of final account. The logical questions at this point are: Why is it necessary to link the causes and effects of dispute and delays and how can the link help the practitioners to prevent or remedy future dispute and delays? Therefore, all parties involved should cooperate to assure that the dispute and delays in construction project can be eliminated in ensuring the closing of final account can be resolved without any problems.

\section{Forms of Contract in Malaysia}

A form of contract is a legally binding agreement between the parties identified in the agreement to fulfil all the terms and conditions outlined in the agreement. A prerequisite requirement for the execution of a contract, amongst other things, is the condition that all the parties to the contract accept the terms of the claimed contract. Construction contracts are basically different from major service contracts. There are various types of form of contract used in construction industry in Malaysia. The selection forms of contract depend on the basis of pricing and the contract strategy that best meet the project objectives. The various types of contract offer different ways of handling pricing, risk transfer, responsibility for performance, cost certainty, and complexity. The process of building procurement involves a series of different specialists or parties in contributing to the work at a different time. It leads to the fragmentation process in construction industry (Murdoch, 2000). Each project participant has particular aims and objectives and it is rare to find contract structures that encourage harmony among these aims.

Thus, the purpose of standard forms of contract is to facilitate the contractual arrangements between actors in a project. Standard forms of contract are readymade terms and conditions when the contract is created (Kwakye, 1997). The standards forms of contract are vary from country to country and from one type of project to another project. These standards are generally used and accepted by different contracting parties. Standard forms of contracts are often criticized as being a compromise containing some defective aspects. It would be practically impossible to devise a standard form of contract that would take account of all eventualities that might occur in a construction project (Andersson and Gunnarsson, 2002). However, the advantage of their adoptions is that with the passage of time, persons using them become familiar with their overall content as well as their particular strengths and weaknesses (Kwakye, 1997).

In Malaysia, there are several standard forms of contracts which are applicable for construction depending on the categories of works and types of clients. Among the several standard forms of contract in Malaysia is the PWD Forms which are compulsory for government works. There are two types of the PWD Forms, PWD Form 203A (Rev. 10/83) (Standard Form of Contract to be used where Bills of Quantities form part of the Contract) and PWD 203 (Rev. 10/83) (Standard Form of Contract to be used based on Drawings and Specifications without Bills of Quantities). In fact, PWD form 203A (Rev. 10/83) is used more often than PWD 203 (Rev. 10/83) form because Bills of Quantities are very often used in Malaysia. Therefore, PWD 203A (Rev. $10 / 83$ ) is taken as the representative standard form of contract in Malaysia (PWD, 2007). The PWD forms are applied for all projects funded by the Malaysian public sector. 
On the other hands, the PAM (PertubuhanAkitek Malaysia) standard forms of contract have been widely used by the local building industry especially for private project in Malaysia (PAM, 2006). Other form of contract used in Malaysia is FédérationInternationale des IngénieursConseils (FIDIC), which is also referred to as the International Federation of Consulting Engineers, produces standard forms of contract for civil engineering construction which are used throughout the world (FIDIC, 1999). FIDIC contracts are often referred to as the international standard.

Besides, the Construction Industry Development Board Malaysia (CIDB) has produced two standard forms of Contract; the CIDB Standard form of Contract for Building Works (2000 Edition) and the CIDB Standard Form of Sub-Contract for Nominated Sub-Contractor. The two forms of contract do not appear to have been widely adopted by the construction industry at this time. Other form of contract in Malaysia is IEM Form of Contract For Civil Engineering Works (as it has now been renamed), or IEM.CE 2011. IEM Conditions of Contract for Works Mainly of Civil Engineering Construction was first published in May 1989. It was modelled very much on PWD 203 Form of Contract and was much used in private sector-financed civil engineering construction works. It has been a little more than two decades since it was published. Therefore, the selection of each forms of contract mentioned above depending on type of project, owner/clients of project, nature of a project and financing involved.

\section{Comparisons of the Closing of Final Accounts according to the Forms of Contract}

Forms of contract to be used should be understood by all parties involved in the construction projects to prevent any disputes or problems in the future, especially in the closing of final accounts. Most of the standard forms of civil engineering contract in Malaysia contain provisions upon which the engineer/quantity surveyor is obliged to settle the final accountand issue a final payment certificate to the contractor within a specified period of time after receipt of the contractor's final account statement.

In basic terms, a final account in construction contracts is the agreed statement of the amount of money to be paid at the end of a project contract by the employer to the contractor. A final account brings about a sense of finality to the negotiations leading up to the agreement of the final account between the parties to the contract. In construction contracts, it is generally a common practice for either the employer (or the employer's representative) and the contractor to sign the final account statement to signify that the final account figure represents the full and final settlement of all claims. The closing of final account negotiations between the contractor and the architect, engineer or quantity surveyor on behalf of the employer will in due course trigger the issue of the final account statement and ultimately, enable the issuance of the final certificate. The comparison of instructions for the closing of final account as mentioned in forms of contract commonly used in Malaysia are described as the following.

PWD Form 203A (Rev.2007): The contract states that the Contractor shall submit full particulars complete with supporting documents within but not than three (3) months after the issuance of the Certificate of Practical Completion. The Superintendent Officer (S.O) shall issue the Final Certificate within three (3) months after the expiry of the Defect Liability Periods for the whole of the Works or three (3) months after the issue of the Certificate of Completion of Making Good Defects (Clause31) (PWD, 2007).

PAM Contract 2006: The contract states that the Contractor shall send to the Architect and Quality Surveyor, all document with supporting of the draft final statement within six (6) months after Practical Completion of the Works (Clause 30.10) (PAM, 2006). 
FIDIC 1st Edition RED BOOK: The contract states that within $\mathbf{5 6}$ days after receiving the Performance Certification; the Contractor shall submit the draft of final statement with supporting documents showing in detail in a form approved by the Engineer (Clause 14.11) (FIDIC, 1999).

In summary, there are significant differences in the forms of contract in terms of time frame for the closing of final accounts in a particular project. The final account is categorized as on-time if it can be resolved within the time period specified in the forms of contract. However, the similarity between the forms of contract is the process of submitting the final payment claim after the Certification of Making Good Defect (CMGD) or Defect Liability Certificate (DLC) was issued. Yet, seeing as the delay is very much affected by disputes within parties in construction projects, it is essential to investigate the cause of the problems which eventually affect the closing of final account.

\section{Causes of Dispute and Delay in the Closing of Final Accounts}

The major factor leading to a project's success is the practice of efficient and timely payment in construction projects. The cause of the problem to closing the final account is because dispute and delay. Dispute occurs in project management is inevitable, yet dispute is manageable. It would exist where there is an incompatibility of interest (Fenn, 1997) and therefore, the management of dispute is to select a dispute resolution mode, namely confronting, compromising, smoothing, forcing and avoiding (Kerzner, 2006).

Dispute is defined as an assertion of opposing views or claims or a disagreement as to rights (Merriam-Webster's Dictionary of Law, 1996). The conflicts and dispute are co-related where the dispute occurs when the contracting parties failed to manage the problems and dissolve the conflict. Carmicheal $(2000,2002)$ also claims that the case where contractor does not receive the payment as a cause of escalated disputes.
Dispute may be resolved in a number of ways using various proceedings. It would not be true to say that all disputes are resolved at court proceedings or other formal or informal settings of alternative dispute resolution methods. Practically, the contracting parties' controversy and adversary would be increased together with the consumption of cost and time once higher stage of dispute resolution applied. The dispute, if not resolved amicably, can lead to arbitration or litigation. They also demonstrated consistency of the law several cases because of negligence to understand term contract for example disputes on misunderstanding (Thomas, 1992) and disputes on interpretation of clauses (Thomas, 1994).

The issue of delay in payment in construction industry is global phenomenon as it is among the most commonly occur. In Malaysia, the impact of this problem had caused a massive destruction to the country's economic and this has tarnished the good image of the local construction industry. When payments due under the contract are delayed or of lesser value than anticipated, the contractor's financial position suffers, and this in turn may affect a project performance (Sears et. Al, 2008; Gould 1997; Antill and Farmer, 1991; O'Brien and Zilly, 1971; Halpin and Woodhead, 1980; Carmechael, 2000).

Therefore, delay in final payment to contractors is observed by this paper as a common cause of dispute in the construction industry all over the world. Although there has been a remarkable progress in Malaysia's construction industry in the recent years, problems arising from payment issues are getting more serious. Thus, this paper proposes that the causes of these delay and dispute can be categorised into three as discussed in the following subsections which are contractors-related, management-related and contractual-related. 


\section{Dispute and Delay Caused by Contractors i.e. Contractor-Related}

Most of the time contractors would blame clients when they receive late payment. Even though this phenomenon is not arguable, the contractors are also among the factors contributing to this issue. This is supported by Reeves (2003) who states that one of the main reasons for delays payment is when there are errors in submitting claims by the contractors. These errors include claims without adequate supporting documents, wrongly calculated claims, submit uncompleted claims and submission without using the right procedures. When these are the cases, contractors need to resubmit the claims after making necessary corrections, which eventually will lead into delay in payment.

Another factor contributed by contractors to the delay in the final accounts closing is when the contractors fail to agree with the valuation of work (Odeh and Battaineh, 2002). The disagreement may cause delay in certifying the amount of final account.This would consequently result in conflicts between clients and contractor. It is no doubt that the claims would not be certified and hence, delay payment will occur. The same problem will also happen even though a contractor carries out his job as per specified in Bill of Quantities and instructions, yet submits claims after the defect liability period. This will eventually take time for the payment to be made to the contractor. Problem also occurs when the contractors do not keep the records properly to claim the final payments.

On the other hand, Odeh and Battaineh (2002) indicate that inadequate experience of the contractor is also an important factor causing the dispute and delay in construction project. This could be linked to the contract awarding procedure where most projects were awarded to the lowest bidder. A contractor with inadequate experience is not able to plan and manage the projects properly and this can lead to disastrous consequences.

\section{Dispute and Delay Caused by Management's Matters i.e. Management- Related}

Main factor contributed to dispute and delays in construction project by clients are when they take longer time than stipulated in the contract to certify the claim. According to Yee and Abdul Rahman (2010), delay in certification by parties involved may also lead to late payment. The parties involved may delay in approving the application for payment claim due to certain reasons which may arise because of his own or other parties fault, for example claims of the design and construction administration services. The obligation of the design professional to issue payment certificates for instance has long been a tedious and dreaded task and therefore often creates numerous liability problems. Although the only real purpose of issuing payment certificates is to inform the owner or lender that the contractor is entitled to payment, these certificates are often used by potential claimants as a basis for many types of legal actions. This obviously leads to late payments in the construction project.

There are also cases where client's employees unethically hold the process of closing the final accounts to obtain some kind of "gift" from contractors to expedite the payment process. This unethical practice has gained attention from various personals in Malaysia construction industry including the Malaysia Prime Minister who insists that construction players, particularly the government servant with this kind of attitude shall be given penalty. Besides, Yee and Abdul Rahman (2010) identify that clients deliberately delay the payment to contractors for their own financial benefits, especially in releasing the retention monies to contractor. 
Various literatures have also shown that unethical behaviours in the construction industry include unfair conduct, negligence, conflict of interest, collusive tendering, fraud and bribery. Furthermore, in terms of professional conduct, it has been identified that the majority of professionals believe that obligations to the client and public are of equal importance (Vee and Skitmore, 2003). Vee and Skitmore (2003) have further classified unethical practices into four general types of actions which are unfair conduct, conflict of interest, collusion, fraud and bribery.

Other problems to the closing of final accounts occur during rationalisation of rates (work price changes) as well as due to the ignorance of Contract Administrator staff in rationalising the rates on time. It usually occurs when the person in charge of the project (i.e. quantity sureyor/engineer) is no longer in service with the company/retire/transferred, thus the closing of final account will be more difficult and tedious. Dispute and delay will also happen when the records (work price changes/variation orders) are not kept properly. Besides, Murali (2006) also identifies that lack of communication between parties is one of the causes and effects of delays faced by Malaysia construction industrydue to non-functional contract administrator. Therefore, the matters specified above should be given due attention in ensuring the final account can be closed successfully.

\section{Dispute and Delay Caused by Contractual Matters i.e. Contractual-Related}

Various forms of contract have established the processes and ruled the closing of final account in construction project. Understanding the processes and ruled it can help the occurrence of disputes. However, problems always occur after receiving the official certificate of payment from the contract administrator. The main question arose is how can he enforce it, i.e. how and when he can finally receive his payments?
For contractors, the answer lies in the particular contractual provisions governing the cardinal issues of the honouring period as well as the remedies available to the contractor in the event of the employer's breach of the said obligation.

Other factor which caused delay and other difficulties in the closing of final accounts is to finalize the final amount of variation orders. Variation order arises for a variety of reasons. Some are foreseeable whilst others are not. Some result from a genuine change of circumstances and others from the design team's own inadequacies. Arain and Low (2006) identify four origin agents of variation orders, including client, consultant, contractor and other changes. Difficulties in resolving variation orders for current or future projects may have a material adverse impact on contractor's financial condition, cash flows and results of operations. If this problem cannot be settled before the project is handed-over to the client, the closing of final account cannot be resolved within the period prescribed.

On the other hand, the delay closing of final accounts also occurs due to maintenance items in the contract documents where the contractors still have not been paid after the expiry of the defect liability period. Any forms of contract including PWD203, PAM, FIDIC and others state that final account will be paid after the defects liability period. These factors slightly give the implication to the delay in the closing final of account in the construction projects.

\section{Impact of Dispute and Delay in the Closing of Final Accounts}

The rapid increase of the delay in the closing of final account nowadays has gone to the point that it tends to decrease the good image of the construction industry in Malaysia. Malay Contractors Association (2006) reveals that some contractors owed RM 100 billion to RM 200 million within four to five years, mostly in final payments. There are even contractors who have to do leasing 
or loans with the bank because of delay in payment. Delay in payment gives bad impacts to contractors, especially contractors with small capital. Besides, it also creates a negative chain effect within the players in the construction industries such as to suppliers, sub-contractors as well as end users. Problems to settle the final account will create further problem in cash flow and finance to the contractor in terms of obtaining of cash flow to perform other construction projects.

Impacts of delays in the closing of final account also represent an additional cost to the contractor where in majority of cases, the employer is anxious to know his ultimate financial commitment. The architect, engineer or the quantity surveyor has a contractual responsibility under the contract to ensure the date stipulated in the contract for completion of the final account is achieved, whilst the contractor should assist in giving prompt provision for subcontractor's and supplier's accounts by taking into account the method of measurement and prices based on agreement as well as providing necessary supporting data.

It is noteworthy to underpin that final payment is influenced by the preparation of final certificate, or final payment certificate as indicated in some contracts, which is a conclusive evidence of all the works that have been completed in accordance with the contract with provision as to the final contract sum. There has been wrongful conception that the contract administrator is obliged to automatically produce a final payment certificate on his best knowledge within the specified period after issuance of the maintenance certificate. Indeed, the lack of understanding of and attention to the significant extent of works involved in the achievement of such final payment certificate should be the origin of problems arising thereof.

Murali and Soon (2007) have identified the following as the major impacts of delay facing by Malaysia construction industry: time overrun, cost overrun, dispute, arbitration, litigation and total abandonment. The mistakes and discrepancies in the contract document give impact on cost overrun and subsequently will affect the preparation of final accounts. The identification of causes and impacts alone does not help the project managers to take appropriate remedial or preventive steps. Thus project managers of contractor need to understand for example what causes delay in the closing of final accounts. Once the factors become clear, the project managers can take proactive steps to avoid such situations.

In term of the impact of dispute in the closing of final account, dispute will lead to the use of arbitration when no mutual decision is achieved in the final accounts closing. In the arbitration process, it is clear that the disputants need an arbitrator whilst an independent expert will act as the decision maker. The parties must agree to the appointment and are bound by the arbitrator's decision. Even so, there are still cases of delayed payment and non-payment in arbitration if not in the court where contractors are still facing problems in receiving their payments. Arbitration and judicature process not only consumed much time and money but also could 'kill' the business. As a contractor, what is the most appropriate action to be taken in securing their payments without effecting their business and cash flow?

In summary, it is clear that the preparation of proper record information at early stage should be done to avoid the problems of dispute and delay in closing of final account. Contract administrator should give reminder to all parties to keep all the records properly. By doing this, it can reduce and avoid problems in the closing of final account after the defect liability period.

\section{On-Time Closing of Final Accounts}

Construction industry in Malaysia faces many problems, such as little co-operation, limited 
trust, different of opinion and ineffective communication resulting in an adversarial relationship among all project stakeholders (Chan, 2003). Such relationship pilots to project delays, difficulty in resolving claims, cost overrun, litigation and a win-lose climate (Moore, Mosley and Slagle, 1992). Therefore, if the above problems are not nipped in the bud, then, these issues will escalate and cause further delay throughout the course of the construction project including the final account closing stage. As such, the final accountis protracted and frequently the delayed and unsettled issues lead to dispute. Pursuant to Baccarini (1999) and Khang and Moe (2008), when all the final account of financial transaction/dues are completed on-time at the closing or completing phase of a project, such project satisfied the end users and all key stakeholders (including contractors).

On the other hand, when the final account closing is completed with a final payment certificate issued by the engineer or quantity surveyor within the contractual prescribed timescale, the closing of the final account for a particular project is classified as on time and satisfied (Ko, 2009). The contractor shall submit full particulars complete with supporting documents after the issuance of the Certificate of Practical Completion for the final payment.

\section{Conclusions}

A construction project is considered as successful if it is completed without any issue within estimated cost, time, duration and prescribed schedule on a methodology that requires sound engineering judgment. According to Shenet al. (2007), the objectives of a construction project are to ensure the financial affordability to the stakeholders and clients, create employment opportunities and competitiveness as well as maintain the needs of future generations. Client or paymasters should practice an efficient system to make sure that the contractor receives the payment accordingly. Hence, delays of final accounts closing can be resolved at the early stage if the documents are kept properly. Delay in the closing of final accounts may also cause problems to contractor in making working capital and eventually lead to bankruptcy. Personal in charge in the project should be maintained especially the project manager until the closing of final accounts is completed. Thus, project managers need to have better understanding of critical success/failure factors in the construction project and how to measure them.

In general, this paper has successfully revealed the of comparisons of forms of contract that have been used in the construction industry in Malaysia. This paper also identifies the causes and impacts of dispute and delay in the closing of final account. It is anticipated that the finding reported in this paper could assist the planning of future strategies and guidelines in ensuring an on-time closing of final account in construction projects in Malaysia. In the future, through comparative studies in other aspects, the reason on why each characteristic of a contract form, and roles and responsibilities contract administrator are formed in ensuring the on-time closing of final account in construction project shall be proven from the viewpoints of history, culture and business practices.

\section{Acknowledgements}

The authors would like to express their sincere gratitude to University of Technology Malaysia for providing the financial support for this paper to be published. The authors are also very grateful to anonymous reviewers for their valuable comments to this paper. This study is financed by the Grant for Research University (GUP) Tier 1 of the University of Technology Malaysia, Johor for research funding under Cost Centre No. Q.K.130000.7140.00H47.

\section{References}

Adams, F. K. (2008). "Risk Perception and Bayesian Analysis of International Construction Contract Risks: The Case of 
Payment Delays in a Developing Economy," International Journal of Project Management, Vol. 26(2), 138-48.

Alston, A. J. \& Miller, W. W. (2001). "Analyzing the Barriers and Benefits Toward Instructional Technology Instruction in North Carolina and Virginia Secondary Agricultural Education Curricula," Journal of Southern Agricultural Education Research, 51(1), $50-62$.

Andersson, C. \& Gunnarsson, Ph. (2002). 'Contract Management: A Way of Increasing Profit in Construction Projects?,' Learning from NCC International's highway construction project in Nicaragua, Chalmers University of Technology, Goteborg, Sweden.

Antill, J. M. \& Farmer, B. F. (1991). 'Engineering Management,' 3rd ed., Wiley, New York, $N Y$.

Arain, \& Low, S. P. (2006). 'The Potential Effects of Variation Orders on Institutional Building Buildings Projects,' The Emerald Research, FAC 23, 11/12, 496-510.

Arditi, D. \& Chotibhongs, R. (2005). "Issues in Subcontracting Practice," Journal of Construction Engineering and Management, Vol. 131(8), 866-76.

Baccarini, D. (1999). 'The Logical Framework Method for Defining Project Success,' Project Management Journal, 30(4), 25-32.

Bennett, J. \& Ferry, D. (1990). "Specialist Contractors: A Review of Issues Raised by Their New Role in Building," Construction Management and Economics, Vol. 8 (3), 25983.

Brown, M. M. (2001). "The Benefits and Costs of Information Technology Innovations: An Empirical Assessment of a Local Government Agency," Public Performance \& Management Review, 24 (4), 351-366.

Carmichael, D. G. (2000). Contracts and International Project Management, A.A. Balkema, Rotterdam.
Carmichael, D. G. (2002). "Disputes and International Projects,” A.A. Balkema, Rotterdam.

Construction Industry Development Board Malaysia (CIDB). (2010).Market Watch Malaysia 2010; Construction Industry, Kuala Lumpur, Malaysia.

Chan, A. P. C., Chan, D. W. M. \& Ho, K. S. K. (2003). "An Empirical Study of the Benefits of Construction Partnering in Hong Kong," Journal of Construction Management and Economics, 21, 523-533.

Chen, H. L. \& Chen, W. T. (2005). "Clarifying the Behavioural Patterns of Contractor Supply Chain Payment Conditions," International Journal of Project Management, $23,463-73$

Chow, K. F. (1993). 'Law and Practice of Construction Contract Claims,' Longman, Singapore.

Fenn, P., Lowe, D. \& Speck, C. (1997). "Conflict and Dispute in Construction," Journal of Construction Management and Economics, 15(6), 513-518.

FIDIC (1999). 'Conditions of Contract for Construction,' International Federation of Consulting Engineer, Switzerland.

Gould, F. E. (1997). 'Managing the Construction Process,' Prentice-Hall, Englewood Cliffs, NJ.

Halpin, D. W. \& Woodhead, R. W. (1980). 'Construction Management,' Wiley, New York, $N Y$.

Hinze, J. \& Tracey, A. (1994). "The Contractor-Subcontractor Relationship: The Subcontractor's View," ASCE Journal of Construction Engineering and Management, 120(2), 274-87.

Kerzner, H. (2006). Project Management - A Systems Approach to Planning, Scheduling, 
and Controlling, John Wiley and Sons, Hoboken, New Jersey.

Khang, D. B. \& Moe, T. L. (2008). "Success Criteria \& Factors for International Development Projects: A Life-cycled-Based Framework," International Journal of Project Management, March, 72-84.

Kwakye, A. A. (1997). 'Construction Project Administration in Practice,, Longman, London.

Kwok, C. K. (2009). "Study of Important Factors Affecting Final Account Settlement Satisfaction of Hong Kong Civil Engineering Projects: Contractor's Perspective," Degree of Engineering Doctorate, City University of Hong Kong.

Malayan Banking Berhad (2011). "Maybank Annual Report 2011," Maybank, Kuala Lumpur.

Moore, C., Mosley, D. \& Slagle, M. (1992). 'Partnering Guidelines for Win-win Project Management,' Project Management Journal, 22(1), 18-21.

Murali, S. \& Soon, Y. W. (2006). 'Causes and Effects of Delays in Malaysian Construction Industry,' International Journal of Project Management, 25(1), 517-526.

Murdoch, J. \& Hughes, W. (2000). Construction Contracts - Law and Management, (3rd Ed.), Spon Press, Great Britain, London.

Navon, R. (1995). "Resource Based Model for Automatic Cash Flow Forecasting," Construction Management and Economics, 13, 501-10.

Nunnally, J. C. (1978). Psychometric Theory, (2nd ed.), McGraw-Hill, New York.

O’Brien, J. J. \& Zilly, R. G. (1971). Contractor's Management Handbook, McGraw-Hill, New York, NY.
Odeh, A. M. \& Battaineh, H. T. (2002). "Causes of Construction Delay: Traditional Contracts," International Journal Project Management, 20, 67-73.

Odeyinka, H. A. \& Kaka, A. (2005). "An Evaluation of Contractor's Satisfaction with Payment Terms Influencing Construction Cash Flow," Journal of Financial Management of Property and Construction, 10(3), 171-80.

PertubuhanAkitek Malaysia (PAM), (2006). "Agreement and Conditions of PAM Contract 2006 (With Quantities)," PAM Publication, Kuala Lumpur.

Pheng, L. S. (1994). "Balancing Construction and Marketing in World Economic Development: The Four Global Scenarios," Journal of Construction Management Economic, 12, 171-182.

Public Work Department Malaysia, (2007). 'PWD 203A Form of Contract Revised 2007, Standard Conventional Contract,' PWD Publication, Malaysia.

Reeves, K. (2003). 'Pay Up,' JUBM Construction News and Views, 1/2003, 4-6.

Rosli Abdul Rashid. (1988). 'The Liability of Construction Project Manager and the Design Teams to the Clients and Buyers,' University of Reading, p. 6.

Sambasivan, M. \& Soon, Y. W. (2007). “Causes and Effects of Delays in Malaysia Construction Industry," International Journal of Project Management, 25, 517-526.

Sears, S. K., Sears, G. A. \& Clough, R. H. (2008). Construction Project Management, 5th ed., Wiley, Englewood Cliffs, NJ.

Service Circular Number 3. (1998). 'Guidelines Provision and Receiveables Gifts in Civil Service,' Malaysia.

Shen, L. Y., Hao, J. L., Tam, V. W. Y. \& Yao, H. (2007). "A Checklist for Assessing Sustainability Performance of Construction 
Projects," Journal of civil engineering and management, XIII (4), 273-281.

Strischek, D. (1995). 'Cash flow projections for contractors revisited,' Journal of Commercial Lending, 77(10), 17-37.

The Economic Planning Unit Prime Minister's Department (EPU). (2010). 'Tenth Malaysia Plan 2011-2015,' Putrajaya.

Thomas, H. R., Smith, G. R. \& Mellott, R. E. (1994). "Interpretation of Construction Contract," Journal of Construction Engineering and Management (ASCE), 120(2), 321-336.

Thomas, H. R., Smith, G. R. \& Ponderlick, R. M. (1992). "Resolving Disputes Based on Misrepresentations," Journal of Construction Engineering and Management (ASCE), 118(3): 472-87.

Tse, R. Y. C. \& Ganesan, S. (1997). “Causal Relationship between Construction Flows and GDP: Evidence from Hong Kong," Journal of Construction Management Economic, 15, 371-376.

Uher, T. E. (1991). "Risks in Subcontracting: Subcontract Conditions," Construction Management and Economics, 9(3), 495-508.

Vee, C. \& Skitmore, M. (2003). "Professional Ethics in the Construction Industry," Engineering, Construction and Architectural Management,10 (2), 117-127.

Yee, K. M. \& Abdul Rahman, H. (2010). "Risk of Late Payment in the Malaysian Construction Industry," Faculty of Built Environment, University of Malaya, Malaysia. 